\title{
Crude palm stearin influences the performance, carcass quality and intestinal morphology of broiler chicks
}

\author{
A.A. Khaskheli ${ }^{*}$ and L. Chou \\ Department of Animal Nutrition, Faculty of Animal Husbandry and Veterinary Sciences, \\ Sindh Agriculture University, Tandojam-70051, Province-Sindh - Pakistan \\ *CorrespondingE-mail: khaskhelias@gmail.com
}

Received July 29, 2020; Accepted January 07, 2021

\begin{abstract}
ABSTRAK
Tujuan utama penelitian ini adalah untuk mengamati kinerja pertumbuhan, hasil karkas, kualitas daging dan morfologi usus ayam broiler terhadap dietary crude palm stearin (CPS). Penelitian dilakukan pada 200 ekor dan dibagi menjadi dua kelompok penelitian, yaitu kelompok kontrol dan kelompok perlakuan CPS dengan 10 ulangan masing-masing 10 ekor. Anak ayam kelompok kontrol diberi pakan basal saja, namun pada kelompok perlakuan CPS anak ayam diberi pakan basal ditambah dengan 3\% CPS. Ayam dipelihara selama 42 hari dan data mengenai parameter penelitian dicatat. Data dianalisis dengan uji-t dan perbedaan dianggap signifikan pada $\mathrm{P}<0,05$. Hasil penelitian menunjukkan perlakuan CPS menunjukkan performan lebih rendah dibandingkan kontrol, yang meliputi berat badan akhir, pertambahan bobot badan harian, rasio konversi pakan, asupan pakan, persentase karkas, fillet, paha atas dan bawah, dan persentase sayap. Kelompok yang diberi CPS memiliki berat hati, limpa, gizzard (ampela) dan lemak abdominal yang lebih rendah dibanding kontrol. Daging dada memiliki nilai shear force dan drip loss yang lebih rendah, sedangkan susut masak ditemukan sebaliknya. Lemak perut memiliki nilai $\mathrm{a} *$ (kemerahan) dan $\mathrm{b} *$ (kekuningan) yang lebih tinggi untuk daging dada dan kulit paha pada anak ayam yang diberi CPS. Kulit dada dan daging paha memiliki nilai $\mathrm{a} *$ dan $\mathrm{b} *$ yang lebih rendah pada anak ayam yang diberi CPS. Tinggi vilus usus, luas vilus, dan kedalaman kripta di duodenum ditemukan jauh lebih tinggi pada ayam yang diberi CPS. Jejunum pada kelompok perlakuan CPS memiliki kedalaman kripta yang lebih tinggi tetapi tinggi vili dan luas vili tetap lebih rendah. Kesimpulannya, CPS mengganggu kinerja pertumbuhan secara keseluruhan, hasil karkas dan kualitas daging tetapi mendukung morfologi usus.
\end{abstract}

Kata kunci : broiler, morfologi intestin, kualitas daging, pasca penetasan, vili

\begin{abstract}
The main objective of the investigation was to observe the growth performance, carcass yield, meat quality, and intestinal morphology of broiler chicks with respect to the dietary crude palm stearin (CPS). The study was conducted on 200 birds and dividing them into two experimental groups viz control and CPS treated group with 10 replications of 10 birds in each. Chicks under the control group were fed basal diet only, however in CPS treated group chicks were fed the basal diet supplemented with 3\% CPS. Birds were reared for 42 days and data regarding different parameters of study was recorded. Data were analyzed by student T-test and differences were considered significant at $\mathrm{P}<0.05$. Results indicated CPS treated group pertaining to lower final body weight, daily weight gain, feed conversion ratio, feed intake, dressing percentage, fillets, thight+drumsticks, and wings percentages. CPS treated group possessed lower liver, spleen, gizzard, and abdominal fat weights. Breast meat holds lower values
\end{abstract}


for shear force, drip loss in CPS treated group, while cooking loss found vice versa. Abdominal fat breast in the meat and thigh skin possessed higher $a^{*}$ (redness) and $b^{*}$ (yellowness) values in CPS treated chicks, while breast skin and thigh meat hold lower $\mathrm{a}^{*}$ and $\mathrm{b}^{*}$ values in CPS treated chicks compared to control. Intestinal villus height, villus area and crypts depth in duodenum found considerably higher in the CPS treated chicks. Jejunum in CPS treated group possessed higher crypt depth but villus height and villus area remained lower. In conclusion, CPS impairs overall growth performance, carcass yield and meat quality but supports the intestinal morphology.

Keywords: broilers, intestinal morphology, meat quality, post hatching, villi

\section{INTRODUCTION}

Oils and fats are major contributors to energy per unit weight in any feed ingredient. There are a lot of fat and oil resources though may be used in broiler's diets, due to lack of appropriate knowledge the use of such energy resources by commercial producers is quite limited (Hake et al., 2005). Among all oils, palm oil is reported as the second most common vegetable oil produced in the world nowadays following soybean oil. It acts as an important multipurpose raw resource in the feed industry (Imoisi et al., 2015). This oil is exceptional compared to all other oils of the vegetable source. In fact it contains a higher concentration of saturated fatty acids. Further, such oils are assumed to contain 10 to 16 percent saturated fatty acids adjoined with triglycerides. Five to Eight percent diglycerides and free fatty acids are also found in palm oil which prominently influences the physical properties (Mohammadreza et al., 2015). It has also been reported that palm oil has polymorphic property and mixing with other fats sources during food manufacturing improves the product texture (Chandrasekharan et al., 2000).

Generally, two key portions may be fractionated from the palm oil. Those key portions include palm stearin and palm olein. Palm stearin is solid and constitutes 30 to $35 \%$, while palm olein is liquid by nature and contributes 65 to $70 \%$. For the production of palm stearin on a commercial scale, fractional crystallization is used. Dry fractionation is the utmost conventional technique of fractional crystallization which is used nowadays. In this process of fractionation, that portion of glycerides is crystallized which solidifies at the normal operating temperature. After the process of solidification solids are separated from the liquid portion however, stearin is named as a higher melting portion (Nusantoro, 2009). Generally, the fractionation process increases the mono-unsaturated oleic acids and subsequently reduces major saturated fatty acids like palmitic acid. Stearin factions may be classified based on carbon numbers such as $\mathrm{C} 48$, C50, and C52 (Undurraga et al., 2001). The efficiency of the fractionation process and the physicochemical properties of the stearin are greatly influenced by the crystallization behavior of the oils as each class of triglyceride molecules has its physicochemical behavior though plays a role either as a solvent or as a crystallizing material (Lai et al., 2000).

Each oil is composed of different types of triglycerides that have different crystallization temperatures, thus crystallization temperature is the key factor that plays a vital role in the process of fractionation. If the temperature is reduced with a lower speed that results in crystallization of such triglyceride molecules though have variable crystallization temperatures. Resultantly crystals of fine size are produced which require higher pressure for filtration. However, with a rapid decrease in temperature, molecules of wide range are crystallized at the same time and bigger granular crystal is produced due to agglomeration (Jirasubkunakorn et al., 2007). Two high melting fractions are attained by dry fractionation namely palm stearin and palm mid fraction. Palm stearin is specially stocked as a fat source for animal use. Being an excellent and cheaper fat source, palm stearin could also potentially be used in broiler feeding (Arima et al., 2007). Therefore the main objective of the present study was to study the influence of crude palm stearin (CPS) on the performance, carcass yield, quality of meat, and intestinal morphology in broilers.

\section{MATERIALS AND METHODS}

\section{Experimental Place}

The research was performed at Poultry Research Station, Department of Animal Science, Kasetsart University, Thailand. All experiments and procedures were carried by trained researchers under the guidelines verified by 
Kasetsart University (KU-AQ570503). Diet was formulated using maize and soybean meal as basal ingredients to meet the nutrients requirement of broilers chicks (Ross 308 strain). Further, palm olein oil, tapioca mash, fish meal, dicalcium phosphate, Premix, L-Methionine, and L-lysine were also included to balance the nutrients needed for the chicks. Formulated diet for chicks under control and CPS treated group contained the same type of ingredients excepting crude palm stearin that was not included in the control group while in the treated group, 3\% Crude Palm Stearin (CPS) was added (Table 1).

\section{Preparation and Assessment of Crude Palm Stearin (CPS)}

Crude palm oil (CPO) was purchased from Sooksomboon Palm Oil Co., Ltd., located in Chonburi province. Oil was subjected to twophase dry fractionation by incomplete crystallization at a controlled temperature. In the first phase, a temperature of $18{ }^{\circ} \mathrm{C} / 12 \mathrm{~h}$ was applied for crystallizing the palm oil and

Table 1. Composition of Experimental Diets

\begin{tabular}{lcc}
\hline \multicolumn{1}{c}{ Ingredients } & $\begin{array}{c}\text { Control } \\
\text { Group }\end{array}$ & $\begin{array}{c}\text { CPS } \\
\text { Treated } \\
\text { Group }\end{array}$ \\
\hline Yellow maize & 45.0 & 45.0 \\
Palm olein oil & 4.2 & 1.11 \\
Crude palm stearin & - & 3.0 \\
Tapioca mash & 14.8 & 14.9 \\
Soybean meal & 22.3 & 20.3 \\
Fish meal & 12.0 & 13.0 \\
Dicalcium phosphate & 1.2 & 1.3 \\
Premix & 0.5 & 0.4 \\
DL-Methionine & 0.2 & 0.3 \\
L-lysine & 0.3 & 0.4 \\
Calculated chemical composition (\%) & \\
Crude protein & 19.00 & 19.00 \\
Ether extract & 7.06 & 7.97 \\
Crude fiber & 3.01 & 3.00 \\
Calcium & 1.01 & 1.02 \\
Available Phosphorus & 0.52 & 0.54 \\
Metabolizable energy & & \\
(kcal/kg) & 3,200 & 3,200 \\
\hline
\end{tabular}

obtaining olien. In the second phase, olien was further fractionated to super olein and palm mid fraction (PMF) by applying a temperature of $12^{\circ} \mathrm{C} / 20$ h. High-performance liquid chromatography (HPLC) and analytical grades chemicals were during the process. Crude palm stearin (CPS) and olein fraction were obtained in the ratio $1: 5$ respectively.

\section{Experimental Design and Procedures}

The experimental trial for the present investigation included a total of Two Hundred $(\mathrm{n}=200)$. Chicks were reared under a cage system, whereby birds were distributed into two groups namely control and CPS treated group with 10 replications of 10 birds in each. Each cage was equipped with a feeder and nipple system, while a plastic tray was set to collect the excreta. Experimental chicks were fasted for 24 hours to empty all remaining alimentary contents and then the experimental diet was started. Chicks under the control group were fed basal diet only, however in CPS treated group chicks were fed the basal diet supplemented with 3\% CPS. Birds were reared for a period of 42 days and data regarding different parameters of the study was recorded. For the growth performance, data on parameters like weight gain, diet intake, and initial and final body weight was gathered during the study period. Feed conversion ratio (FCR) was calculated by using the formula. Carcass characteristics and visceral organs were studied by slaughtering the birds and recording the live weight, breast, fillets, thigh+drumsticks, and wings percentages. Further, the weight of liver, heart, proventriculus, gizzard, spleen, gallbladder, and abdominal fat were also noted for observing the effect of CPS on different visceral organs. Meat quality was assessed in terms of shear force and percentages of drip loss, cooking loss, thawing loss in breast and thigh meat. Using standard protocols $\mathrm{L}^{*}$ (lightness), a* (redness), and $b^{*}$ (yellowness) values were calculated for thigh skin, thigh meat, breast skin, breast meat, and abdominal fat. For intestinal morphology, the small intestines of slaughtered chicks from both groups were sampled and examined under an electron microscope for villus area, height, and crypts depth of ileum, jejunum, and duodenum.

\section{Data Analysis}

Collected data were statistically analyzed using the SPSS statistical package version 8.1. Student T-test was used for comparing the means 
of CPS treated and control groups. Differences were considered significant at $\mathrm{P}<0.05$.

\section{RESULTS AND DISCUSSION}

\section{Results}

The present research was conducted to observe the influence of crude palm stearin on the growth, carcass yield, quality of meat and intestinal morphology of chicks whereby 3\% crude palm stearin was incorporated into the basal diet and its effects were studied in comparison with the control group. Results regarding the influence of CPS on the growth parameters are depicted in Table 2. Results indicate that the chicks in CPS treated group pertained significantly $(\mathrm{P}<0.05)$ lower values for final body weight, average daily weight gain, and feed intake compared to chicks under the control group. Although means showed variation among the values but statistically no significant difference was noticed.

Table 3 shows the findings regarding the effects of dietary CPS on carcass yield, visceral organs, and meat quality of broiler chicks. Dressing, fillets, thight + drumstick, and wings percentages were found significantly $(\mathrm{P}<0.05)$ poor in the chicks under CPS treated group compared to control group, however breast percentage was found completely inverse to these findings, whereby chicks in CPS treated group possessed significantly $(\mathrm{P}<0.05)$ higher breast percentage compared to control. Liver, spleen, gizzard, and abdominal fat also showed a similar trend. Chicks in CPS treated group possessed lower values for liver, spleen, gizzard, and abdominal fat compared to the control group, however heart and proventriculus were found inverse. In CPS treated groups chicks possessed higher heart and proventriculus weights compared to control. Regarding breast meat quality results indicated lower values for shear force, drip loss in CPS treated group compared to control group, while cooking loss appeared vice versa, whereby CPS treated chicks pertained breast meat having higher cooking and thawing loss contrast to control group. Thigh meat also showed relevant change pattern in the results. Thigh meat of CPS treated chicks hold lower values against shear force and drip loss compared to control group, whereas cooking and thawing loss appeared vice versa. Chicks in CPS treated group possessed significantly $(\mathrm{P}<0.05)$ higher cooking and thawing loss compared to chicks in the control group.

Concerning the dietary influence of CPS on meat, skin, and abdominal fat color, results are presented in Table 4. The table shows significantly $(\mathrm{P}<0.05)$ higher $\mathrm{a}^{*}$ and $\mathrm{b}^{*}$ values for breast meat, and thigh skin of chicks in the CPS treated group compared to the control group, while $\mathrm{L}^{*}$ values were found vice versa. CPS treated group pertained lower $\mathrm{L}^{*}$ values for breast meat and thigh skin. Breast skin and thigh meat also showed relevant change patterns in the results. Breast skin and thigh meat of chicks in the CPS treated group possessed lower $a^{*}$ and $b^{*}$ values compared to chicks in the control group, whereas $L^{*}$ values appeared opposite. Chicks in CPS treated group possessed higher $\mathrm{L}^{*}$ values compared to the control group. Abdomen fat showed significantly $(\mathrm{P}<0.05)$ higher $\mathrm{a}^{*}$ value in CPS treated group, whereas $L^{*}$ and $b^{*}$ values app eared opposite to these findings. Chicks in CPS tr eated group possessed lower $L^{*}$ and $b^{*}$ values co mpared to the control group. Regarding the influence of dietary CPS on villus area, villus height, and depth of crypts, results are presented in Figure 1. The figure shows that villus height, villus area, and crypt depth in the duodenum were found significantly $(\mathrm{P}<0.05)$ higher in the chicks under CPS treated group compared to the chicks in the control group, however in case of ileum

Table 2. Growth Performance of Broiler Chicks in Control and CPS Treated Group

\begin{tabular}{lccc}
\hline \multirow{2}{*}{ Parameters } & \multicolumn{2}{c}{ Experimental Groups } & \multirow{2}{*}{ P-Values } \\
\cline { 2 - 3 } & Control & $3 \%$ CPS treated & \\
\hline Final body weight $(\mathrm{g} / \mathrm{b})$ & $2665.1 \pm 42.6$ & $2648.28 \pm 49.5$ & 0.131 \\
Average daily gain $(\mathrm{g} / \mathrm{b} / \mathrm{d})$ & $66.7 \pm 1.2$ & $66.2 \pm 1.4$ & 0.152 \\
Feed intake $(\mathrm{g} / \mathrm{b})$ & $4563.4 \pm 59.0$ & $4536.1 \pm 58.8$ & 0.124 \\
FCR & $1.96 \pm 0.04$ & $1.95 \pm 0.03$ & 0.110 \\
\hline
\end{tabular}


Table 3. Carcass Yield, Visceral Organ and Meat Quality of Broiler Chicks in Control and CPS Treated Groups

\begin{tabular}{lrrr}
\hline \multicolumn{1}{c}{ Study Parameters } & \multicolumn{2}{c}{ Treatment groups } & \multirow{2}{*}{ P-Values } \\
\cline { 2 - 3 } & \multicolumn{1}{c}{ Control } & $3 \%$ CPS & \\
\hline Carcass yield & & & 0.123 \\
Dressing (\%) & $88.71 \pm 0.65$ & $86.63 \pm 0.49$ & 0.111 \\
Breast (\%) & $23.15 \pm 1.00$ & $23.78 \pm 1.03$ & 0.124 \\
Fillets (\%) & $6.44 \pm 0.08$ & $6.44 \pm 0.07$ & 0.213 \\
Thighs + Drum sticks (\%) & $31.34 \pm 0.41$ & $29.83 \pm 0.38$ & 0.121 \\
Wings (\%) & $10.39 \pm 0.06$ & $10.12 \pm 0.06$ & \\
Visceral organs & & & 0.321 \\
Liver (\%) & $4.23 \pm 0.05$ & $3.92 \pm 0.19$ & 0.011 \\
Spleen (\%) & $0.092 \pm 0.006$ & $0.080 \pm 0.004$ & 0.231 \\
Heart (\%) & $0.41 \pm 0.015$ & $0.45 \pm 0.019$ & 0.100 \\
Gizzard (\%) & $2.01 \pm 0.072$ & $2.93 \pm 0.051$ & 0.010 \\
Proventriculus (\%) & $0.28 \pm 0.008$ & $0.28 \pm 0.012$ & 0.201 \\
Abdominal fat (\%) & $2.43 \pm 0.090$ & $2.31 \pm 0.062$ & \\
Breast meat quality & & & 0.112 \\
Shear force (g) & $4534 \pm 59.2$ & $4467 \pm 78.7$ & 0.131 \\
Drip loss (\%) & $10.8 \pm 1.1$ & $9.5 \pm 0.1$ & 0.340 \\
Cooking loss (\%) & $22.0 \pm 0.8$ & $27.3 \pm 3.4$ & 0.103 \\
Thawing loss (\%) & $11.1 \pm 0.2$ & $11.6 \pm 0.4$ & 0.241 \\
Thigh meat quality & & & 0.145 \\
Shear force (g) & $1712 \pm 56.7$ & $1664 \pm 42.6$ & \\
Drip loss (\%) & $9.5 \pm 0.3$ & $27.8 \pm 0.4$ & \\
Cooking loss (\%) & $12.1 \pm 0.7$ & $14.3 \pm 0.6$ & \\
Thawing loss (\%) & & & \\
\hline
\end{tabular}

results appeared vice versa. Ileum under the CPS treated group contained lower villus height, villus area, and crypts depth compared to chicks under the control group. Concerning jejunum, Figure 1 indicates that the chicks in CPS treated group although possessed higher crypts depth compared to chicks under the control group, but villus height and villus area were found significantly $(\mathrm{P}<0.05)$ lower in CPS treated group in comparison with the control group. The scanning electron microscopy recorded the cellular alteration in the villus apical surface and views are shown in Figure 2. Duodenal cellular morphology of chicks showed great variability in the appearance. The surface of villi possessed several epithelial cells in the control group, while in CPS treated group ample cell groups were seen though were grouped surrounding central sulcus. Further, various cell clusters were observed in ileum and jejunum. Cells were grouped with several protruded epithelia around the central sulcus. On other hand, the apical surface of villi in the control group was composed of many single epithelial cells only.

\section{Discussion}

The present investigation was performed to observe the influence of crude palm stearin on the growth, carcass yield, quality of meat, and intestinal morphology of chicks whereby 3\% 
Table 4. Color of Meat, Skin and Abdominal Fat of Broiler Chicks in Control and CPS Treated Group

\begin{tabular}{|c|c|c|c|}
\hline \multirow{2}{*}{ Parameters } & \multicolumn{2}{|c|}{ Experimental Diet } & \multirow{2}{*}{$P$-values } \\
\hline & Control & $3 \% \mathrm{CPS}$ & \\
\hline \multicolumn{4}{|l|}{ Breast meat } \\
\hline $\mathrm{L}^{*}$ & $62.21 \pm 0.76$ & $60.91 \pm 3.24$ & 1.055 \\
\hline$a^{*}$ & $6.76 \pm 0.33$ & $7.03 \pm 0.34$ & 1.090 \\
\hline $\mathrm{b}^{*}$ & $13.93 \pm 0.70$ & $14.02 \pm 0.62$ & 1.087 \\
\hline \multicolumn{4}{|l|}{ Breast skin } \\
\hline $\mathrm{L}^{*}$ & $73.95 \pm 1.60$ & $74.87 \pm 0.80$ & 1.000 \\
\hline$a^{*}$ & $6.13 \pm 0.25$ & $6.00 \pm 0.28$ & 0.901 \\
\hline$b^{*}$ & $18.53 \pm 0.83$ & $17.15 \pm 0.91$ & 1.057 \\
\hline \multicolumn{4}{|l|}{ Thigh meat } \\
\hline $\mathrm{L}^{*}$ & $64.28 \pm 0.86$ & $66.59 \pm 0.64$ & 1.982 \\
\hline$a^{*}$ & $7.73 \pm 0.32$ & $7.19 \pm 0.31$ & 0.451 \\
\hline$b^{*}$ & $15.61 \pm 0.51$ & $14.18 \pm 1.25$ & 1.111 \\
\hline \multicolumn{4}{|l|}{ Thigh skin } \\
\hline $\mathrm{L}^{*}$ & $77.54 \pm 0.71$ & $74.27 \pm 0.49$ & 2.342 \\
\hline$a^{*}$ & $5.01 \pm 0.23$ & $5.13 \pm 0.26$ & 0.890 \\
\hline$b^{*}$ & $14.72 \pm 1.05$ & $14.73 \pm 0.94$ & 0.121 \\
\hline \multicolumn{4}{|l|}{ Abdominal fat } \\
\hline $\mathrm{L}^{*}$ & $78.50 \pm 0.84$ & $74.38 \pm 1.12$ & 2.456 \\
\hline$a^{*}$ & $7.96 \pm 0.45$ & $9.88 \pm 0.54$ & 2.167 \\
\hline$b^{*}$ & $25.03 \pm 0.72$ & $23.07 \pm 0.63$ & 1.789 \\
\hline
\end{tabular}

$L^{*}$ : Lightness $\quad a^{*}$ : Redness $\quad b^{*}$ : Yellowness

crude palm stearin was supplemented to the basal diet, and its effects were studied in contrast to control group. Results indicated CPS treated chicks pertained considerably lower final body weight, average daily weight gain, FCR, and feed intake compared to chicks under the control group. Our findings are not in line with (Zulkifli et al., 2003) who otherwise reported that the addition of fat stimulates feed and ME energy consumption in poultry. It may be because the reported study focused on fat and Metabolizable energy, however in our study one fraction of crude palm oil i.e. crude palm stearin was applied. Nwoche et al. (2003) reported quite relevant results when provided palm oil in broilers diet on different levels. They reported that the addition of $4 \%$ palm oil results in better growth performance compared to $2,3,5$, and $6 \%$ supplementation, however in the present study similar kind of change pattern was noted in the results. Findings regarding the effects of dietary CPS on carcass yield, visceral organs, and meat quality of broiler chicks showed that dressing percentage, fillets, thight+drumstick, and wings percentages were found prominently poor in the chicks under CPS treated group compared to control, however, breast percentage was found completely inverse to these findings, whereby chicks in CPS treated group possessed higher breast percentage compared to control. Chicks in CPS treated group possessed lower values for liver, spleen, gizzard, and abdominal fat, however, heart and proventriculus were found inverse. Regarding breast meat quality results indicated lower values for shear force, drip loss in CPS treated group compared to the control group, while cooking loss appeared vice versa. Thigh meat of CPS treated chicks hold lower value for shear force and drip 

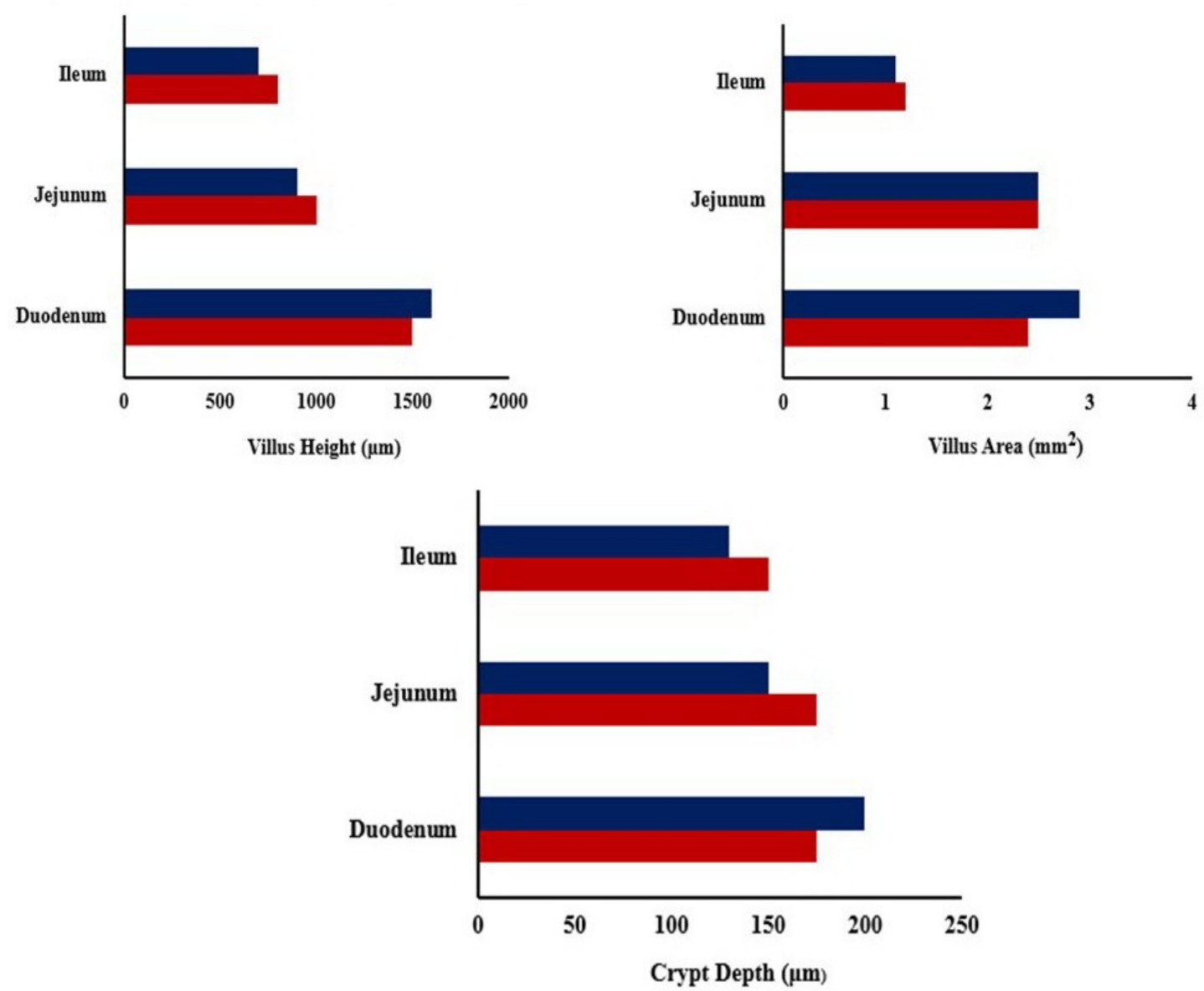

Figure 1. Villus height, villus area and crypt depth of the duodenum, jejunum and ileum of broiler chicks in control and CPS treated groups.

- $3 \%$ CPS Control

loss. Reginatto et al. (2000) also reported supportive results when studied the performance and composition of the carcass in broilers with respect to dietary protein and energy. Crespo et al. (2002) reported results are also in agreement with the current study. They stated that fat deposition is contraindicated with dietary polyunsaturated fatty acids. Hosseini-Vashan et al. (2010) also reported similar results pattern when compared the growth performance and carcass characteristics of broiler chickens fed diets with various energy and constant energy to protein ratio. However, reported findings of (Lessire, 2001) were found the inverse to current results. They reported a positive influence of palm stearin on body and carcass composition especially the deposition of fat in the abdomen, however, in the present study, it was found the opposite. It may be argued that in the reported study different bird species were focused which could have influenced the change in the results, whereas in our study broilers were focused. Change in the results may also be related to the location and environmental influences on the chicks during the experimental phase.

Our study further indicated higher $\mathrm{a}^{*}$ and $\mathrm{b}^{*}$ values against breast meat, and thigh skin of chicks in the CPS treated group compared to breast meat of chicks in the control group, while $L^{*}$ values were found vice versa. Breast skin and thigh meat of chicks in the CPS treated group holds lower $\mathrm{a}^{*}$ and $\mathrm{b}^{*}$ values compared to chicks in the control group, whereas $L^{*}$ values appeared opposite. Abdomen fat showed considerably higher $\mathrm{a}^{*}$ values in CPS treated group, whereas L $*$ and $b^{*}$ values appeared opposite to these finding s. Ayed et al. (2015) also reported a similar change pattern in the results with respect to oil supplementation in the diet as in the current study was noted. The villus height, villus area, and crypt depth in the duodenum were found considerably 


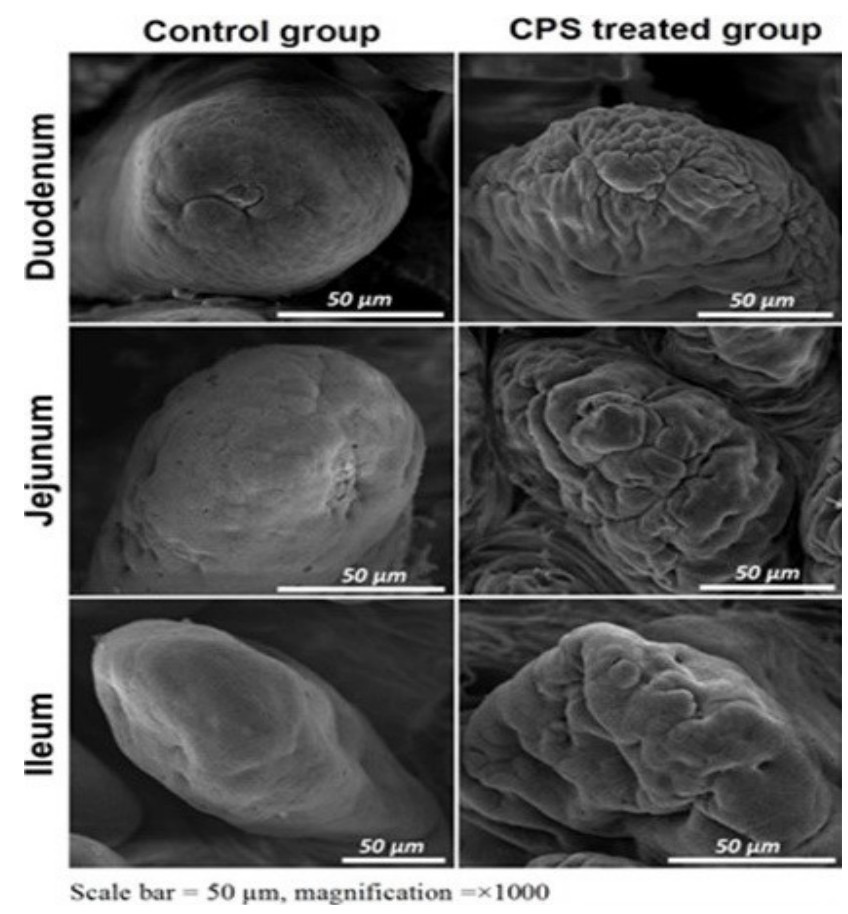

Figure 2. Scanning Electron Microscopic Observations of Apical Surface of Duodenum, Jejunum and Ileum of Broiler Chicks in Control and CPS Treated Group

higher in the CPS treated chicks, however, in the case of ileum results appeared vice versa. Concerning jejunum, the chicks under CPS treated group although possessed higher crypts depth compared chicks under the control group, but villus height and villus area were found considerably lower. Bobadoye et al. (2008) also stated supportive findings. They suggested that GIT weight and morphology in broilers is considerably improved by dietary supplementation with palm oil. Duodenal cellular morphology of chicks among different groups showed great variability in the appearance. The surface of villi possessed several epithelial cells in the control group, while in CPS treated group ample cell groups were seen though were grouped surrounding central sulcus. Hosseini-Vashan et al. (2010) and Reginatto et al. (2000) also supported our study. They reported various cell clusters in ileum and jejunum. They also stated cells were grouped with several protruded epithelia around the central sulcus. At present, it was observed that the supplementation of CPS improves the intestinal morphology but does not support the growth. Crude palm stearin act as an antagonist for nutrients absorption that resulted in a lower growth rate compared to birds in the control group. However, intestinal morphology might have improved as a result of stimulatory action, of poor nutrients absorption phenomenon, on intestinal cells.

\section{CONCLUSION}

The current study concludes that the practice of using crude palm stearin in broiler chicks does not have any positive influence on the overall growth performance, carcass yield and meat quality, however it significantly improves the intestinal morphology especially the duodenum which could be a plus point for crude palm stearin to be used in broilers' diet.

\section{ACKNOWLEDGEMENTS}

The authors are thankful to all staff members of Poultry Research Station, Department of Animal Science, Kasetsart University, Thailand for providing a research facility and conducive environment for current research.

\section{REFERENCES}

Arima, S., T. Ueji, S. Ueno, A. Ogawa and K. Sato. 2007. Retardation of crystallizationinduced destabilization of PMF-in-water 
emulsion with emulsifier additives. Coll. and Surf. 55(2):98-106.

Ayed, H.B., H. Attia and M. Ennouri. 2015. Effect of oil supplemented diet on growth performance and meat quality of broiler chickens. Adv. Tech. in Bio. \& Med. 4 (1):2379-1764.

Bobadoye, A.O., G.E. Onibi, A.N. Fajemisin, O.O. Olasupo and B.O. Bobadoye. 2008. Replacing maize with palm oil sludge in broiler chicken diets: Effect on carcass characteristics, organ weight and muscle development. Int. J. Sust. Crop Prod. 3 (4): $1-5$.

Chandrasekharan, N., K. Sundram and Y. Basiron. 2000. Changing nutritional and health perspectives on palm oil. Brunei Int. Med. J. 2(3):417-427.

Crespo, N. and E. Esteve-Garcia. 2002. Dietary polyunsaturated fatty acids decrease fat deposition in separable fat depots but not in the remainder carcass. Poult. Sci. 81(3):512518

Hake, H.M., A. Mehmet, B. Anitha, M. Moorthy and V. Nididi. 2005. Effect of various dietary fat sources on performance and body fatty acid composition of broiler chickens. J. Anim. Vet. Adv. 6(4):1317-1322

Hosseini-Vashan, S.J., A.R. Jafari-Sayadi, A. Golian, G. Motaghinia and M. Namvari. 2010. Comparison of growth performance and carcass characteristics of broiler chickens fed diets with various energy and constant energy to protein ratio. J. Anim. Vet. Adv. 9(6):2565-2570

Imoisi, O.B., G.E. Ilori, I. Agho and J.O. Ekhator. 2015. Palm oil; its nutritional and health implications. J. Appl. Sci. Environ. Man. 19(2):27-133.

Jirasubkunakorn, W., A.E. Bell, M.H. Gordon and K.W. Smith. 2007. Effects of variation in the palm stearin:palm olein ratio on the crystallisation of a low-trans shortening. F. Chem. 103(2):477-485.

Lai, O.M., H.M. Ghazali, F. Cho and C.L. Chong. 2000. Enzymatic transesterification of palm stearin:anhydrous milk fat mixture using 1,3-specific and non-specific lipases. F. Chem. 70(4):221-225.

Lessire, M. 2001. Matièregrassealimentaire et composition lipidique des volailles. Rev. Prod. Anim. INRA. 14(6):365-370

Mohammadreza, K., N. Masoomeh and C. Fatemeh, C. 2015. Physico-chemical properties; fatty acid profile and nutrition in palm oil. Arch. Adv. in Biosci. 6(5):117134.

Nusantoro, B.P. 2009. Physicochemical properties of palm stearin and palm mid fraction obtained by dry fractionation. Agritechnol. 29(1):154-158.

Nwoche, G.N., E.C. Ndubuisi and F.C. Iheukwumere. 2003. Effects of dietary palm oil on the performance of broiler chicks. Int. J. Agri. Rural Dev. 4(3):81-86

Reginatto, M.F., A.M.L. Ribeiro, A.M. Penz, A.M. Kessler and E.L. Krabbe. 2000. Effect of energy; energy: protein ratio and growing phase on the performance and carcass composition of broilers. Revista Brasileira de Ciencia Avicola. 2(2):229-237

Undurraga, D., A. Markovits and S. Erazo. 2001. Cocoa butter equivalent through enzymatic interesterification of palm oil midfraction. Proc. Biochem. 36(4):933-939.

Zulkifli, I., J. Ginsos, P.K. Liew and J. Gilbert. 2003. Growth performance and Newcastle disease antibody titres of broiler chickens fed palm-based diets and their response to heat stress during fasting. Archiv-furGeflugelkunde. 67(4):125-130. 